\title{
Effectivness on Traning in Celebrity Fashion Limited
}

\author{
Magdalene Peter, S. Fabiyola Kavitha
}

Keywords: Questionnaire Method, Research, Effectiveness

\section{INTRODUCTION}

Getting ready is commonly understood as correspondence composed at a described people to make capacities, modifying conduct, and growing expertise. All things considered, getting ready revolves exclusively around what ought to be know. [20], [22], [24] Guidance is a progressively drawn out term process that wires the targets of planning and explains why certain information must be know. Guidance underscores the legitimate foundation of the material presented both getting ready and preparing impel learning, a system that modifies data and direct through instructing and experience. The assessment model portrayed here identifies with both getting ready and guidance.[1],[3],[5]Along these lines, in this record, "preparing" alludes to the two procedures. As opposed to casual preparing (which is implanted in many occurrences of human trade), formal preparing mediations have expressed objectives, substance, and systems for guidance. Our expectation is to offer a general way to deal with mediation adequacy investigate that tends to formal preparing crosswise over setting and themes. The model incorporates essential and auxiliary information gathering with subjective and quantitative investigations so the advantages of each examination system can be connected to the assessment of preparing adequacy[2 ],[4],[6]

Revised Manuscript Received on July 22, 2019.

Magdalene Peter, Department of MBA, Bharath Institute of Higher Education and Research, Chennai, India.

Email: magdalene.bsb@gmail.com

Dr. S. Fabiyola Kavitha, Department of MBA, Bharath Institute of Higher

Education and Research, Chennai, India.

Email: fabiyolakavitha@gmail.com

\begin{abstract}
This project has been conducted on "Effectiveness of training" in CELEBRITY FASHION LIMITED. The Primary Objective of this project is that to measure the effectiveness of training. The Secondary Objectives are to study the Effectiveness of training. A Research Methodology was followed for the effective functioning of the research. The Research design used in the study is descriptive. The sampling technique used by the researcher is non-probability sampling. Questionnaire method was followed to collect primary data and the secondary data was collected from the organization and books available. The resulted analysis helped us to understand the satisfaction level of employees in the training and development activities carried out by CELEBRITY FASHION LIMITED.
\end{abstract}

\section{OBJECTIVES OF THE STUDY}

To measure the viability of preparing given by CELEBRITY FASHION LIMITED to their representatives

To measure the viability of preparing given by

CELEBRITY FASHION LIMITED to their representatives

$\square$ To evaluate on execution of the mentor.

To examination the adequacy of the course substance of preparing.

To assess the viability of preparing result.

To investigate the effect of preparing framework on preparing.

$\square$ To propose appropriate measure to upgrade the adequacy of preparing program.

\section{RESEARCH METHODOLOGY}

Research technique is an academic development and along these lines the term should be used in a particular sense. This assessment contains describing and reexamining issue, arranging hypothesis or suggested course of action, gathering, dealing with, surveying data, making determination, touching base at goals lastly circumspectly testing the conclusion to choose on the off chance that they fit the figuring theory

[7], [9], [11]

\section{RESEARCH DESIGN DEFINITON}

Research technique is an academic activity and in like manner the term should be used in a particular sense.[25], [27],[29] This investigation includes portraying and reexamining issue, figuring hypothesis or proposed course of action, gathering, dealing with, surveying data, making thinking, landing at goals lastly circumspectly testing the conclusion to choose on the off chance that they fit the arranging hypothesis. [8], [10],[12]

\section{V.SAMPLING METHOD}

The scientist has utilized comfort inspecting technique to gather the samples.[13],[15],[17]This accommodation examining strategy is a non-likelihood testing under which the inspecting units are picked basically based on the comfort of the exploration. [19], [21],[23]

\section{A. SAMPLING SIZE}

The determined sample size for this study is 43 numbers 


\section{B. METHOD OF DATA COLLECTION:}

Data collection for this study consists of two types of data.

$>$ Primary Data

$>$ Secondary Data

Primary Data

$>$ The primary data was collected from employees

$>$ Questionnaire was used for this purpose which is administered by the supervisor. [26], [28], [30]

\section{Secondary Data}

$>$ The secondary data source can be found more quickly and cheaply than primary date. [31], [33]

$>$ Information is gathered from organization's pamphlets, organization sites, talking about with the higher authorities and individual records establishing the optional information accumulation. [13], [15],[17]

\section{RESULTS AND DISCUSSIONS}

Respondents regarding the level of output

\begin{tabular}{|l|c|c|c|}
\hline S. No. & Working style & No of Respondents & Percentage \\
\hline 1. & Increase in production & 20 & 46 \\
\hline 2. & Same as before training & 18 & 42 \\
\hline 3. & Less productive & 5 & 12 \\
\hline & TOTAL & 43 & 100 \\
\hline
\end{tabular}

From the above analyzed table $46 \%$ of the respondents belong to increase in production and $42 \%$ of the respondent belong to same as before training and less productive belong to $12 \%$.

\begin{tabular}{|l|c|c|c|}
\hline S. No. & Working quality & No of Respondents & Percentage \\
\hline 1. & Best quality & 25 & 59 \\
\hline 2. & Same as before training & 12 & 28 \\
\hline 3. & Inferior quality & 6 & 13 \\
\hline & TOTAL & 43 & 100 \\
\hline
\end{tabular}

Inference: From the above analyzed table 59\% of the respondents belong to best quality and $28 \%$ of the respondent belong to same as before training and $13 \%$ of the respondent belong to inferior quality.

\section{CONCLUSTION}

To conclude, the trainees' evaluation on effectiveness of training under CELEBRITY FASHION LIMITED was found to be very good. If Aishwarya Traders trust enhances its training system based on the above findings and suggestions it would help the trainees to improve their training level to increase their competency and help in planning the career and for their future achievement in target. [14], [16],[18]

\section{REFERENCES}

1) BharthVajan R., Ramachandran S.,Psychographic dimensions of training,2016,International Journal of Pharmacy and Technology,V-8,I-4,P-23727-23729

2) Balakrishnan P., Bharthvajan R.,A study on human resource planning in hospitals in Chennai City,2014,International Journal of Applied Engineering Research,V-9,I-22,P-7503-7507

3) Priyadarsini P., Bharthvajan R.,Role of emotional intelligence training programme in reducing the stress of the nurses,2014,International Journal of Applied Engineering Research,V-9,I-22,P-7411-7421

4) Kerinab Beenu G., Bharthvajan R.,Empirical analysis on the cosmetic buying behavior of young women in South India,2014,International Journal of Applied Engineering Research,V-9,I-22,P-7361-7366

5) Balakrishnan P., Bharthvajan R.,Whistling in the wind,2014,International Journal of Applied Engineering Research,V-9,I-22,P-7586-7593

6) Krishnan B., Peter M.,Health hazards of Indian Bpo employee-an alarming issue,2014,International Journal of Applied Engineering Research,V-9,I-22,P-7336-7341

7) Kerinab Beenu G.H., Peter M.,Role of insurance in economic development,2014,International Journal of Applied Engineering Research,V-9,I-22,P-7532-7539

8) Balakrishnan P., Peter M., Priyadarsini P.,Efficiency of safety measures for wellbeing of employees in manufacturing industry,2014,International Journal of Applied Engineering Research,V-9,I-22,P-7376-7382

9) Anbarasi M., Praveen Kumar S.,Online sales promotions of herbal products and its effectiveness towards tanisha.com,2019,Indian Journal of Public Health Research and Development,V-10,I-1,P-195-200

10) Anbarasi M., Praveen Kumar S.,Various online marketing and promotions strategies to improve the validation towards the organic products in the pharmaceutical sectors,2019,Indian Journal of Public Health Research and Development,V-10,I-1,P-263-269

11) Loganathan R., Praveen Kumar S.,Grievance handling a key factor for solving issues of employees in an organization,2014,International Journal of Applied Engineering Research,V-9,I-22,P-7483-7491

12) Loganathan R., Praveen Kumar S.,Study on preference of private label brands in super and Hypermarkets, 2014,International Journal of Applied Engineering Research,V-9,I-22,P-7327-7335

13) Smitha M., Praveen Kumar S.,Understanding stress and its managementamong the nurses in Chennai city,2014,International Journal of Applied Engineering Research,V-9,I-22,P-7560-7565

14) Kerinab Beenu G.H., Praveen Kumar S.,A study on the investment behavior of Chennai investors in mutual fund schemes,2014,International Journal of Applied Engineering Research,V-9,I-22,P-7520-7525

15) Loganathan R., Praveen Kumar S.,Retention strategies key for organizational productivity,2014,International Journal of Applied Engineering Research,V-9,I-22,P-7443-7447

16) Pavithra J., Ganesan M., Brindha G.,State wise analysis of microfinance sector in India,2016,International Journal of Pharmacy and Technology,V-8,I-4,P-23417-23432

17) Pavithra J., Ganesan M.,A comparative study on microfinance in India and abroad,2016,International Journal of Applied Business and Economic Research,V-14,I-8,P-5471-5476

18) Pavithra J., Ganesan M.,A study on awareness and impact of micro-financial schemes,2016,International Journal of Applied Business and Economic Research,V-14,I-8,P-5449-5460

19) Senthilmurugan P., Pavithra J.,Consumer preference towards organised retailing with reference to Big Bazaar,2014,International Journal of Applied Engineering Research,V-9,I-22,P-7469-7475

20) Senthilmurugan P., Pavithra J.,Implication of social media marketing in growing healthcare industry,2014,International Journal of Applied Engineering Research,V-9,I-22,P-7448-7456

21) Loganathan R., Pavithra J.,Consumer perception towards private label brand over other brands in super markets and hypermarkets,2014,International Journal of Applied Engineering Research,V-9,I-22,P-7355-7360

22) Kerinab Beenu G., Pavithra J.,Tradeâ€"off between liquidity and profitability in logistics industry,2014,International Journal of Applied Engineering Research,V-9,I-22,P-7398-7401

23) Kerinab Beenu G., Pavithra J.,A study on the prospective consumerâ€(M perception towards utility cars in Chennai city,2014,International Journal of Applied Engineering Research,V-9,I-22,P-7526-7531

24) Pavithra J., Dilli Babu P., Ambuli T.V.,A study on budgetary control at Maruti Service Masters, Chennai,2014,International Journal of Applied Business and Economic Research,V-12,I-2,P-151-161

25) Pavithra J., Dilli Babu P., Ambuli T.V.,A study on customer satisfaction of retro Garments Pvt Ltd, Chennai,2014,International Journal of Applied Business and Economic Research,V-12,I-2,P-381-391 
26) Kerinab Beenu G.H., Pavithra J., Senthilmurugan P.,A study on the influence of promotional activities for TATA ARIA among consumers in Chennai,2014,International Journal of Applied Engineering Research,V-9,I-22,P-7572-7578

27) Vijayaragavan S.P.,An investigative expert that's general FBG sensors,International Journal of Mechanical Engineering and Technology,V-8,I-8,PP-1500-1505,Y-2017

28) Vijayaragavan S.P.,Equalization routing protocol for Wi-Fi sensor strategy,International Journal of Mechanical Engineering and Technology,V-8,I-8,PP-1662-1666,Y-2017

29) Karthik B., Kiran Kumar T.V.U., Vijayaragavan P., Bharath Kumaran E.,Design of a digital PLL using 0.35 $\hat{\mathrm{I}}^{1 / 4 \mathrm{~m}}$ CMOS technology,Middle East Journal of Scientific Research,V-18,I-12,PP-1803-1806,Y-2013

30) Kanniga E., Selvaramarathnam K., Sundararajan M.,Kandigital bike operating system,Middle - East Journal of Scientific Research,V

31) Jasmin M., Vigneshwaran T., Beulah Hemalatha S.,Design of power aware on chip embedded memory based FSM encoding in FPGA,International Journal of Applied Engineering Research,V-10,I-2,PP-4487-4496,Y-2015

32) Jasmin M.,Optimization techniques for low power VLSI circuits,Middle East Journal of Scientific Research,V-20,I-9,PP-1082-1087,Y-2014

33) Jasmin M., Vigneswaran T.,Fuzzy controller for error control of on - Chip communication,2017 International Conference on Algorithms, Methodology, Models and Applications in Emerging Technologies, ICAMMAET 2017,V-2017-January,I-,PP-1-5,Y-2017

\section{AUTHORS PROFILE}

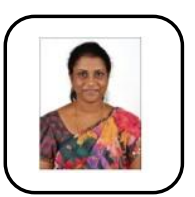

Magdalene Peter Assistant Professor, Department of MBA, Bharath Institute of Higher Education and Research, Chennai, India.

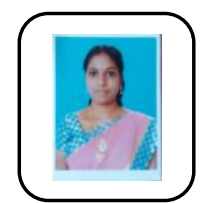

Dr.S. Fabiyola Kavitha Associate Professor, Department of MBA, Bharath Institute of Higher Education and Research, Chennai, India. 